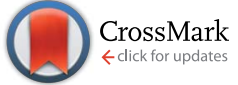

Cite this: RSC Adv., 2016, 6, 65976

\title{
Antibacterial properties of silver dendrite decorated silicon nanowires $\dagger$
}

\author{
Hashim Alhmoud, Bahman Delalat, Xavier Ceto, Roey Elnathan, Alex Cavallaro, \\ Krasimir Vasilev and Nicolas H. Voelcker*
}

\begin{abstract}
In this work, we report on the antibacterial properties of silicon nanowires (SiNWs) generated by via metalassisted chemical etching (MACE) against Escherichia coli (E. coli) and Staphylococcus aureus (S. aureus) bacteria strains. The results demonstrate that the antibacterial action can be attributed to the layer of silver (Ag) dendrites found on the surface of the SiNWs as a natural by-product of the MACE reaction, thus eliminating the need for a second surface modification step with an antibacterial agent. Furthermore, a 100 fold increase in bacterial adherence to SiNWs by virtue of their unique morphology is also demonstrated compared to flat silicon. We observed negligible toxicity exhibited by the SiNWs towards mammalian cells, in addition to very low rates of attachment of the mammalian cells to the SiNWs. This combination of characteristics makes these nanowire substrates an interesting alternative to other biomaterials for use in medical implants and wound dressings to combat bacterial infections.
\end{abstract}

Received 26th May 2016

Accepted 5th July 2016

DOI: 10.1039/c6ra13734b

www.rsc.org/advances

processes have been explored. The bactericidal effects of SiNWs

\section{Introduction}

Vertically aligned silicon nanowires (SiNWs) have been investigated in the past few years due to their diverse properties and myriad of applications in the optical, ${ }^{\mathbf{1 , 2}}$ nano-electronics, ${ }^{3}$ sensing, ${ }^{4-7}$ and cell-material interfaces. ${ }^{8-10}$ They belong to a class of one-dimensional semiconductors that can be easily fabricated through several established processes. ${ }^{11-14}$ Their unique morphology and biocompatibility have also made them a promising and viable platform for cell therapy and tissue engineering. ${ }^{15}$

Additionally, SiNWs have been investigated in the context of photothermal materials for the treatment of cancer cells, ${ }^{16}$ as well as antimicrobial and bactericidal substrates. ${ }^{17-19}$ The development of bactericidal substrates has become a major challenge as part of an effort to control and prevent hospitalacquired infections (HAI) and as antibacterial coatings for medical implants. ${ }^{20}$ To that end, bactericidal substrates including disinfectant-releasing surfaces, $\mathrm{Ag}$ and $\mathrm{Cu}$ releasing surfaces, and light-sensitive bactericides $\left(\right.$ e.g. $\left.\mathrm{TiO}_{2}\right)$ have been developed, and in some cases commercialized. ${ }^{20}$

Ivanova et al. demonstrated that SiNWs fabricated through reactive-ion-etching (RIE) have been shown to have strong bactericidal activity against Pseudomonas aeruginosa, Staphylococcus aureus, and Bacillus subtilis purely via sub-micron mechanical stress. ${ }^{21}$ However, due to the complexity and high cost of RIE, and scalability issues, alternative SiNW fabrication

Future Industries Institute, University of South Australia, University Boulevard, $X$ Building, Mawson Lakes, SA 5095, Australia.E-mail: nico.voelcker@unisa.edu.au

$\dagger$ Electronic supplementary information (ESI) available. See DOI: 10.1039/c6ra13734b fabricated by means of metal-assisted chemical etching (MACE) have been previously showcased, but only after incorporating antibacterial agents into the substrates following fabrication. For example, Lv et al. demonstrated the antimicrobial effects of MACE-fabricated SiNWs decorated with $\mathrm{Ag}$ nanoparticles (AgNP) deposited from solution. ${ }^{19}$ Similarly, Fellahi et al. investigated the antimicrobial effects of SiNWs laced with $\mathrm{Ag}$ and $\mathrm{Cu}$ nanoparticles that were also deposited from $\mathrm{Ag}$ and $\mathrm{Cu}$ salt solutions. ${ }^{17}$ SiNW have also been modified with polymers ${ }^{22}$ and antibiotics ${ }^{23}$ in order to obtain antimicrobial activity.

Another attribute that an antibacterial surface should demonstrate is the ability to promote bacterial cell adhesion preferentially by either utilizing a capture agent, or through the clever utilisation of the surface morphology. We posit that a synergistic strategy of enhanced bacterial adhesion and bactericidal activity would significantly enhance the efficacy of a particular antibacterial substrate, and act as a bacterial 'flytrap'. Indeed, the work of $\mathrm{Li}$ et al. ${ }^{18}$ has shown that SiNWs fabricated through MACE and modified with concanavalin A effectively capture bacteria and that lysozyme immobilized on the SiNW induces bacterial cell wall damage and cell death.

In this work, we demonstrate that vertically aligned SiNWs, etched via the MACE process, demonstrate effective bacterial capturing properties against Gram-positive and Gram-negative bacterial species, without the necessity of surface modification with chemical agents or biomolecules. We also show that the residual $\mathrm{Ag}$ dendrites, left over from the MACE etching reaction, dissolve and efficiently kill bacterial cells in close vicinity of the SiNWs, due to the antibacterial action of $\mathrm{Ag}$ at high effective concentration. 


\section{Experimental section}

\subsection{Materials and reagents}

Flat silicon wafers ( $3^{\prime \prime}$ p-type 3-6 $\left.\Omega \mathrm{cm}\right)$ were obtained from Siltronix (France) and used as received. Sulfuric acid $\left(\mathrm{H}_{2} \mathrm{SO}_{4}\right.$, 95-97\%) and hydrofluoric acid ( $\mathrm{HF}, 48 \%$ ) were purchased from Scharlau Chemie (Chem-Supply Pty. Ltd. Australian representation). Hydrogen peroxide $\left(\mathrm{H}_{2} \mathrm{O}_{2}, 30 \%\right)$ was purchased from Merck (Australia) and nitric acid $\left(\mathrm{HNO}_{3}, 70 \%\right)$ from SigmaAldrich (Australia). Tryptic soy buffer (TSB) was obtained from Oxoid Chemicals (Fisher Scientific, UK). Luria Broth Agar (LBAgar) dried powder was purchased from Fluka Analytical (Australia). All other reagents/solvents were supplied by SigmaAldrich (Australia) unless otherwise specified.

\subsection{SiNW fabrication}

Flat Si wafers were first cleaned by ultrasonication for $5 \mathrm{~min}$ in acetone, ethanol, and MilliQ water. Afterwards, the wafer was immersed in a pre-heated piranha solution $\left(2: 1 \mathrm{H}_{2} \mathrm{SO}_{4}: \mathrm{H}_{2} \mathrm{O}_{2}\right.$; $75^{\circ} \mathrm{C}$ ) for $30 \mathrm{~min}$, followed by vigorous washing with MilliQ water and drying in a compressed $\mathrm{N}_{2}$ gas stream. A solution of 4.8 $\mathrm{M} \mathrm{HF}$ and $0.02 \mathrm{M} \mathrm{AgNO}_{3}$ was prepared in $10 \mathrm{~mL}$ of MilliQ water in a Teflon reaction vessel $(20 \mathrm{~mL})$. The Si wafer was cut into $2 \times 2 \mathrm{~cm}^{2}$ pieces and the cut pieces were immersed in the $\mathrm{HF}$ etching solution at room temperature for durations ranging from $30 \mathrm{~min}$ to $90 \mathrm{~min}$ as specified in the text. The Si pieces, now containing SiNW arrays were washed extensively with MilliQ water to remove any traces of HF and loosely attached agglomerates of $\mathrm{Ag}$, then dried under a $\mathrm{N}_{2}$ gas stream.

\subsection{Preparations of overnight bacterial cultures}

E. coli (ATCC 25922) and S. aureus (ATCC 29213) were obtained from respective frozen stock solutions, streak-plated on LB-agar plates and incubated overnight at $37{ }^{\circ} \mathrm{C}$. Following that, a colony was picked from each plate and used to innoculate 5 $\mathrm{mL}$ of TSB. The innoculated TSB solutions were incubated at 37 ${ }^{\circ} \mathrm{C}$ overnight for a period of $24 \mathrm{~h}$ and recovered the next day. The overnight solutions were then diluted to $10^{8}$ colony forming units per $\mathrm{mL}\left(\mathrm{CFU} \mathrm{mL} \mathrm{m}^{-1}\right)$ on the basis of turbidity $\left(\mathrm{OD}_{600}\right)$ measurements.

\subsection{Determining bacterial adhesion efficiency}

Diluted bacterial solutions $\left(10^{8} \mathrm{CFU} \mathrm{mL} \mathrm{m}^{-1}, 60 \mu \mathrm{L}\right)$ were incubated over SiNW samples and flat Si $\left(5 \times 5 \mathrm{~mm}^{2}\right)$ for $1 \mathrm{~h}$, followed by removal of the bacterial solution, washing the samples with $1 \times$ PBS (7.2 pH) twice, saline solution $(0.14 \mathrm{M} \mathrm{NaCl}$, $7.2 \mathrm{pH}$ ) once, and immersion in BacLight ${ }^{\mathrm{TM}}$ Live/Dead assay staining solution (as prepared previously) for $15 \mathrm{~min}$ in the dark. The samples were then washed once again with saline solution once, and $1 \times$ PBS twice. The samples were then fixed by immersion in $4 \%$ formaldehyde at room temperature in the dark for 15 min, followed by washing the samples with PBS, MilliQ water, $60 \%$ ethanol, $90 \%$ ethanol, and 100\% ethanol for the gradual dehydration of the samples.
The samples were characterized using a Nikon Eclipse Ci-L upright microscope, fitted with a Nikon DS-File digital camera, and a CoolLED pE-100 excitation source $(470 \mathrm{~nm})$. Following fluorescence microscopy, the samples were characterized using SEM. Image analysis and bacterial counts were performed using the open source software ImageJ.

Bacterial counts involved the capture of fluorescence microscopy images showing both flat Si and SiNWs coated with fluorescing bacterial cells. For each substrate $(n=3)$, three consecutive images were captured at three random locations across each surface. The images were then converted to black and white binary formats. The threshold was adjusted so that the majority of the background noise was subtracted from the actual fluorescence emitted by individual cells. ImageJ's particle counting algorithm was then utilized to provide a bacterial count estimate $L_{\mathrm{T}}$. Given that the area imaged by the microscope in each case was equivalent, the data was normalized to (no. of bacterial cells per $\mathrm{cm}^{2}$ ), and reported as such in the text.

\subsection{Measuring Ag ion release over time}

For the purpose of measuring the $\mathrm{Ag}^{+}$release kinetics from the SiNW surfaces, three etching durations were used, namely $30 \mathrm{~min}, 60 \mathrm{~min}$, and $90 \mathrm{~min}$ etched SiNWs were fabricated in triplicates $\left(25 \mathrm{~mm}^{2}\right)$ in order to compare the amount of $\mathrm{Ag}^{+}$ released from each sample. For each set of triplicate samples, three different sets were prepared and immersed in $1 \mathrm{~mL}$ of acetate buffer $(0.1 \mathrm{M}, \mathrm{pH} 4.0)$. Following incubation at $37^{\circ} \mathrm{C}$ for 12,24 , and $48 \mathrm{~h}$ for each of the sets, the buffer solution was recovered and the quantification of released $\mathrm{Ag}$ was achieved by differential pulse adsorptive stripping voltammetry (AdSV) measurements employing a $\mu$ STAT $8000 \mathrm{P}$ potentiostat (DropSens, Spain) controlled with the provided software package.

The measurement cell was formed by a glassy carbon electrode (GCE, $3 \mathrm{~mm}$ diameter, BAS Inc., West Lafayette, USA) as the working electrode, a $\mathrm{Ag} / \mathrm{AgCl}$ reference electrode (BAS Inc., West Lafayette, USA) and a platinum wire as counter electrode, which were placed into a Faraday cage.

Electrochemical conditions were as follows: a deposition potential $\left(E_{\mathrm{dep}}\right)$ of $-0.5 \mathrm{~V}$ was applied during $120 \mathrm{~s}$ under stirring, followed by a rest time $\left(t_{\mathrm{eq}}\right)$ of $5 \mathrm{~s}$, after which the potential was swept from $-0.1 \mathrm{~V}$ to $+0.5 \mathrm{~V} v s$. $\mathrm{Ag} / \mathrm{AgCl}$ with a step potential $\left(E_{\text {step }}\right)$ of $4 \mathrm{mV}$, while applying a pulse with an amplitude $\left(E_{\text {pulse }}\right)$ of $50 \mathrm{mV}$ and width $\left(t_{\text {pulse }}\right)$ of $10 \mathrm{~ms}$. An electrochemical cleaning stage between measurements was performed, consisting in the application of a potential of $+0.5 \mathrm{~V}$ during $120 \mathrm{~s}$ under stirring.

Prior to samples measurement, the GCE was activated by cycling the potential between $-0.4 \mathrm{~V}$ and $+0.5 \mathrm{~V}$ at $100 \mathrm{mV} \mathrm{s}^{-1}$ in acetate buffer ( $\mathrm{pH} 4.0)$, and stored in the same medium.

\subsection{Calculating $\mathrm{Ag}$ ion minimum inhibitory concentration (MIC) for $E$. coli and $S$. aureus}

Overnight bacterial cultures in TSB were prepared for both bacterial strains. The overnight cultures were diluted to $10^{8} \mathrm{CFU} \mathrm{mL} \mathrm{m}^{-1}$ using turbidity measurements. Several dilutions of $\mathrm{AgNO}_{3}$ in TSB were prepared beforehand which were 
comprised of $100,10,1,0.1$, and $0.0 \mu \mathrm{g} \mathrm{mL} \mathrm{m}^{-1}$. The overnight cultures were diluted in $\mathrm{AgNO}_{3}$ containing TSB and then incubated at $37{ }^{\circ} \mathrm{C}$ for $24 \mathrm{~h}$. During the incubation period, $\mathrm{OD}_{600}$ measurements were acquired every $2 \mathrm{~h}$. The measurements were carried out in triplicates. The second iteration of $\mathrm{AgNO}_{3}$ concentrations were prepared between 10 and $100 \mu \mathrm{g} \mathrm{mL}^{-1}$, and the same experimental procedure as above was repeated for measuring the increase in turbidity.

\section{Results and discussion}

Silver compounds and solutions have been historically used as antiseptic agents prior to the discovery of antibiotics. Due to the recent rise in antibiotic resistance in multiple strains of bacteria such as methicillin-resistant $S$. aureus (MRSA), vancomycinresistant Enterococcus (VRE) and multi-drug-resistant M. tuberculosis (MDR-TB), Ag-based delivery systems have re-emerged as viable alternatives in the prevention and treatment of infectious diseases. $^{24}$

One of the main commercial uses of AgNPs is their incorporation into apparel, paints, wound dressings, cosmetics, and plastics for the purpose of conferring antibacterial properties to those products. ${ }^{25}$ By virtue of the MACE process, it is possible to achieve an Ag delivery scaffold based on SiNWs since nanostructured $\mathrm{Ag}$ agglomerates are left over after fabrication.

\subsection{Fabrication of SiNWs}

SiNWs were fabricated according to previously described protocols. $^{11-13}$ Briefly, a p-type flat silicon substrate was immersed in a solution of hydrofluoric acid (HF) and silver nitrate $\left(\mathrm{AgNO}_{3}\right)$, and was allowed to react in a sealed Teflon container at room temperature for the durations of $30 \mathrm{~min}, 60$ min, and $90 \mathrm{~min}$, respectively. The surfaces were washed vigorously with MilliQ water in order to remove loosely attached $\mathrm{Ag}$ agglomerates off the surface. Scanning electron microscopy (SEM) (Fig. 1) shows that the resulting disordered SiNWs structures were consistent in morphology with previous reports by Zhang et al. ${ }^{13}$ and others ${ }^{11,12}$ in terms of SiNW diameter and length. Ag dendrites were observed intertwined with the vertically aligned SiNWs, as well as smaller Ag agglomerates residing at the base of the SiNWs. The formation of $\mathrm{Ag}$ dendrites as a result of electroless deposition has been investigated in detail by Peng et al. ${ }^{26}$ and Qiu et al. ${ }^{27}$

Previous studies have shown that $\mathrm{Ag}^{0}$ deposition is electrochemical in nature. At the silicon/solution interface, simultaneous anodic and cathodic processes occur while the charge is exchanged through the silicon wafer. ${ }^{28} \mathrm{Ag}^{+}$ions are reduced randomly into local $\mathrm{Ag}^{0}$ nanoclusters. The nanoclusters act as catalytic seeds for further $\mathrm{Ag}^{+}$reduction through a cathodic process as described in Peng et $a .^{26}$ and others. ${ }^{27-29}$ Subsequently, a reduction-nucleation-growth cycle occurs where $\mathrm{Ag}^{0}$ forms a chain-like network. As a result, $\mathrm{Ag}$ dendritic nanostructures are formed, driven by decreasing surface energy, in addition to further Ag nanocluster deposition. Each Ag dendrite is anchored to the surface by a seed Ag nanocluster. Given enough time, these dendrites grow in length concurrently with the silicon etching reaction, resulting in the development of SiNW structures intertwined with elongated Ag dendrites across the surface as can be seen in Fig. 1B (yellow arrows). The Ag nanoclusters that were initially deposited are also visible at the base of the SiNWs in Fig. 1B (red arrows).

The random nature of $\mathrm{Ag}$ deposition is thought to be responsible for the random arrangement of SiNWs on the $\mathrm{Si}$ wafer. A key advantage of this process is that the nanostructured Ag dendrites and agglomerates exist as a natural by-product of the etching process. We set out to test whether these Ag deposits could be utilized as effective antimicrobial therapeutics due to their size and surface area.

\subsection{Determining the bacterial adhesion efficiency on SiNWs}

Reports in the literature seem at odds regarding what factors promote or inhibit bacterial adhesion. Some reports asserted that surface roughness, bacterial type, and bacterial morphology (i.e. spherical, rod-shaped, etc.) had the most profound influence on the bacterial adhesion behaviour. ${ }^{30-32}$ After reviewing the recent literature regarding the effect of nanotextured surfaces on bacterial adhesion, Crawford et al. $^{33}$ concluded that bacterial cells tended to attach in the interspaces between high aspect-ratio structures given that these spaces could accommodate the size of the bacterial cells, therefore the results differed between the various bacterial strains. The authors argued that the bacteria benefitted from the 'sheltering effect' provided by such structures. On the other hand, reports by Ivanova et al. and other authors who investigated natural antibacterial surfaces such as the cicada insect wing: ${ }^{34}$ or taro and lotus leaves ${ }^{35}$ suggested that such nanostructured surfaces and their artificially created counterparts demonstrated anti-biofouling properties which prevented bacterial adhesion, and in some cases resulted in bactericidal effects. It is our opinion that the effects demonstrated by these surfaces in terms of bacterial adhesion was purely caused by the dimensions of the nanostructures relative to the bacterial cell sizes, as was postulated by Meng et al. ${ }^{30}$

The studies reviewed above show that although the overall surface area afforded by nanotexturing of the surface affects bacterial adhesion behaviour, that effect depends largely on the size of the bacterial cells relative to the dimensions of the nanostructures. Bacterial cells take advantage of appropriately sized nanostructures to adhere and excrete extracellular matrices to form biofilms. In cases where the crevices between the nanostructures are too small to accommodate bacterial cells, the opposite effect is observed, where bacterial cells fail to form adhesion focal points with the surface as is observed with structures found on lotus leaves and cicada wings. Consequently, the surface acquires anti-biofouling properties even though it has a large surface area by virtue of the nano-scale textures.

The morphology of SiNWs affords a 3-dimensional (3D) scaffold onto which bacterial cells can potentially attach in preference to flat surfaces given that the inter-nanowire spacing is large enough to accommodate both $E$. coli (500-700 nm wide and $\sim 2 \mu \mathrm{m}$ in length) and $S$. aureus (700-800 $\mathrm{nm}$ diameter). 

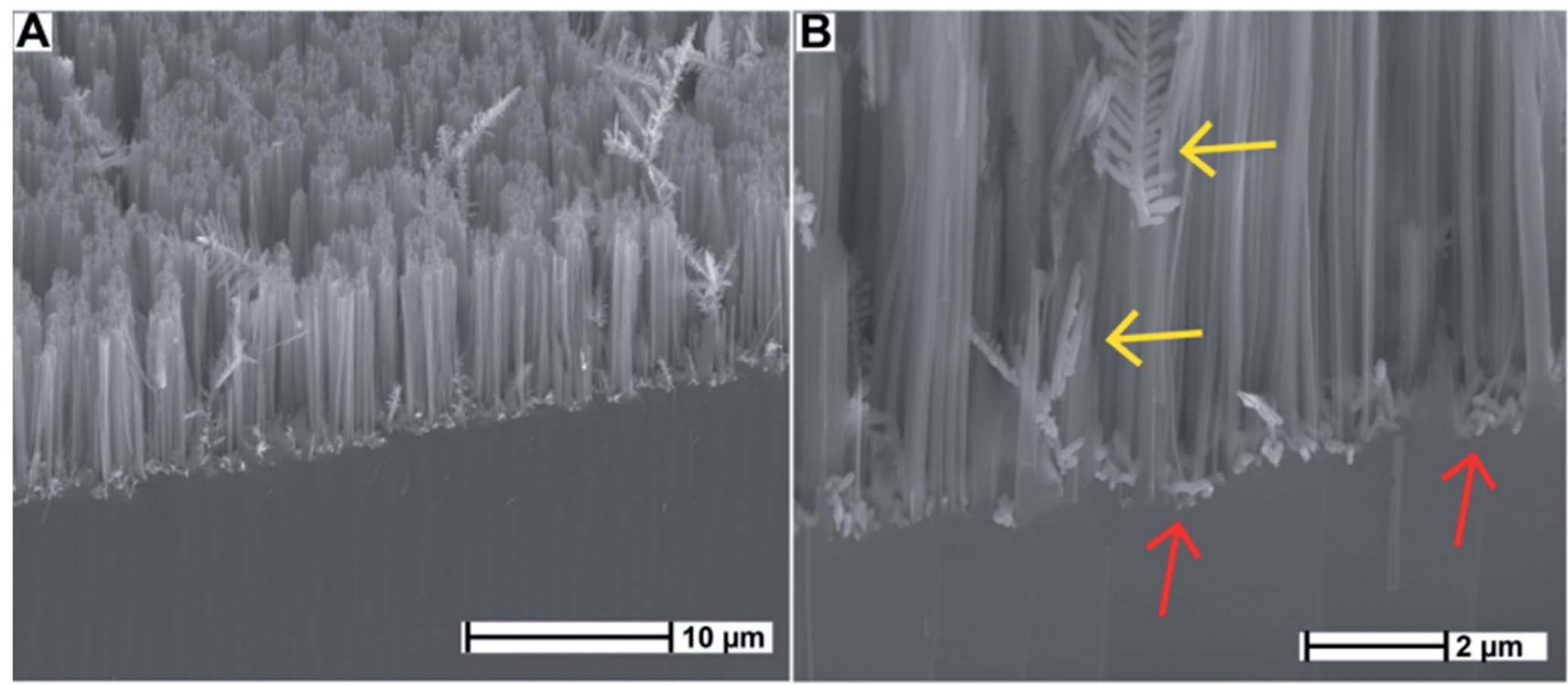

Fig. 1 SEM cross-sections of SiNWs fabricated via MACE. The samples shown were etched for 30 min at room temperature. Panel (A) shows the vertically-aligned SiNWs attached at their base to the silicon substrate (scale bar $=10 \mu \mathrm{m}$ ). The SiNWs were $5 \mu \mathrm{m}$ in length and ranged from $50-$ $150 \mathrm{~nm}$ in diameter. Panel (B) shows a high magnification view of the cross-section where the Ag dendrites and agglomerates are visible (scale $\mathrm{bar}=2 \mu \mathrm{m})$. The Ag dendrites resemble fractal plant leave-shaped formations intertwined with the SiNWs, where the central vein can reach up to several $\mu \mathrm{m}$ in length and the side veins were $0.5-3 \mu \mathrm{m}$ in length (yellow arrows). The smaller Ag agglomerates at the base of the SiNWs were also visible with sizes in the range of $100-300 \mathrm{~nm}$ (red arrows).

Experiments were hence carried out to determine the extent of bacterial attachment to SiNWs (treated with concentrated $\mathrm{HNO}_{3}$ to dissolve and remove the surface-bound $\mathrm{Ag}$ dendrites) as compared to flat Si. Samples were incubated in $1 \mathrm{~mL}$ of freshly prepared tryptic soy buffer (TSB) solution containing $108 \mathrm{CFU} \mathrm{mL} \mathrm{mL}^{-1}$ of either Gram-negative E. coli or Gram-positive $S$. aureus bacteria. Following $1 \mathrm{~h}$ of incubation at $37^{\circ} \mathrm{C}$, the samples were stained with BacLight ${ }^{\mathrm{TM}}$ Live/Dead stain and fixed using formaldehyde solution. Samples were analysed by means of fluorescence microscopy and SEM to confirm the presence of bacterial cells (Fig. 2). The inter-nanowire spacing was estimated using image processing software applied to top-view SEM micrographs of the SiNWs surface, and was measured to be 1.5 $\pm 0.5 \mu \mathrm{m}$ (Fig. 2D and $\mathrm{H}$ ).

Fluorescently labeled $E$. coli readily attached onto SiNWs whilst only few bacterial cells were observed on flat Si (Fig. 2A and C). On average, $488 \pm 370$ cells per $\mathrm{cm}^{2}$ of Gram-negative $E$. coli cells were attached to flat $\mathrm{Si}$, vs. $16157 \pm 1791$ cells per $\mathrm{cm}^{2}$ attached to SiNWs (Fig. S1 $\dagger$ ). Analysis of variance (ANOVA) yielded a $p$-value of $<0.00309$ at $95 \%$ confidence. These averages were calculated from three separate samples for each bacterial strain and surface type combination, and for each combination, three fluorescence microscopy images were analyzed $(n=3)$. The same trend was noticed for Gram-positive $S$. aureus bacteria, as is shown in Fig. 2E and G. Similarly, an average of $458 \pm 284$ cells per $\mathrm{cm}^{2}$ of $S$. aureus cells were found attached to flat Si compared to $59941 \pm 16138$ cells per $\mathrm{cm}^{2}$ attached to SiNWs, with a $p$-value of $<0.00012$ at $95 \%$ confidence. For both Gram-negative and Gram-positive bacteria, the results confirm that bacterial cells prefer a $3 \mathrm{D}$ nanostructured morphology onto which they can attach.
From the SEM micrographs, it was possible to deduce that $E$. coli cells formed aggregates comprizing of tens of individual cells interlaced together, which were either supported by the side walls of the SiNWs, or rested on the tips (Fig. 2D). This was in contrast to $E$. coli on flat $\mathrm{Si}$, where individual units composed of 1-3 bacterial cells were sporadically spread-out across the surface (Fig. 2B). Likewise, for $S$. aureus, units of 1-3 of the round-shaped bacteria were seen across the flat Si surface at a low density (Fig. 2F). However, on SiNWs, the $S$. aureus cells formed aggregates of between 5 and 10 individual cells in close proximity to other aggregates (Fig. $2 \mathrm{H}$ ), while being supported either in between the SiNWs or on their tips.

From these results, it was determined that the fabricated SiNWs resulted in approximately a 100 fold increase in cell capturing efficiency compared to flat $\mathrm{Si}$ without requiring any surface modification with chemical or biological capture agents.

Promoting bacterial adhesion on surfaces seems to be counter-intuitive since it is associated with facilitating biofilm formation and subsequent biofouling of the surface. This has been a main concern when designing nanostructured surfaces, and it is rightly so, given that biofilms have been associated with increased resistance to antibiotics, ${ }^{36}$ as well as being the primary cause of persistent infections. ${ }^{37}$ Here we argue that by promoting the first stage of biofilm formation, namely, the initial attachment and formation of a monolayer of bacterial cells, the SiNWs array creates an entrapping environment to bring the bacteria in close proximity of the $\mathrm{Ag}$ dendrites and nanoparticles, which then exert their cytotoxic effects at high effective concentration. ${ }^{\mathbf{3 8 - 4 0}}$ 

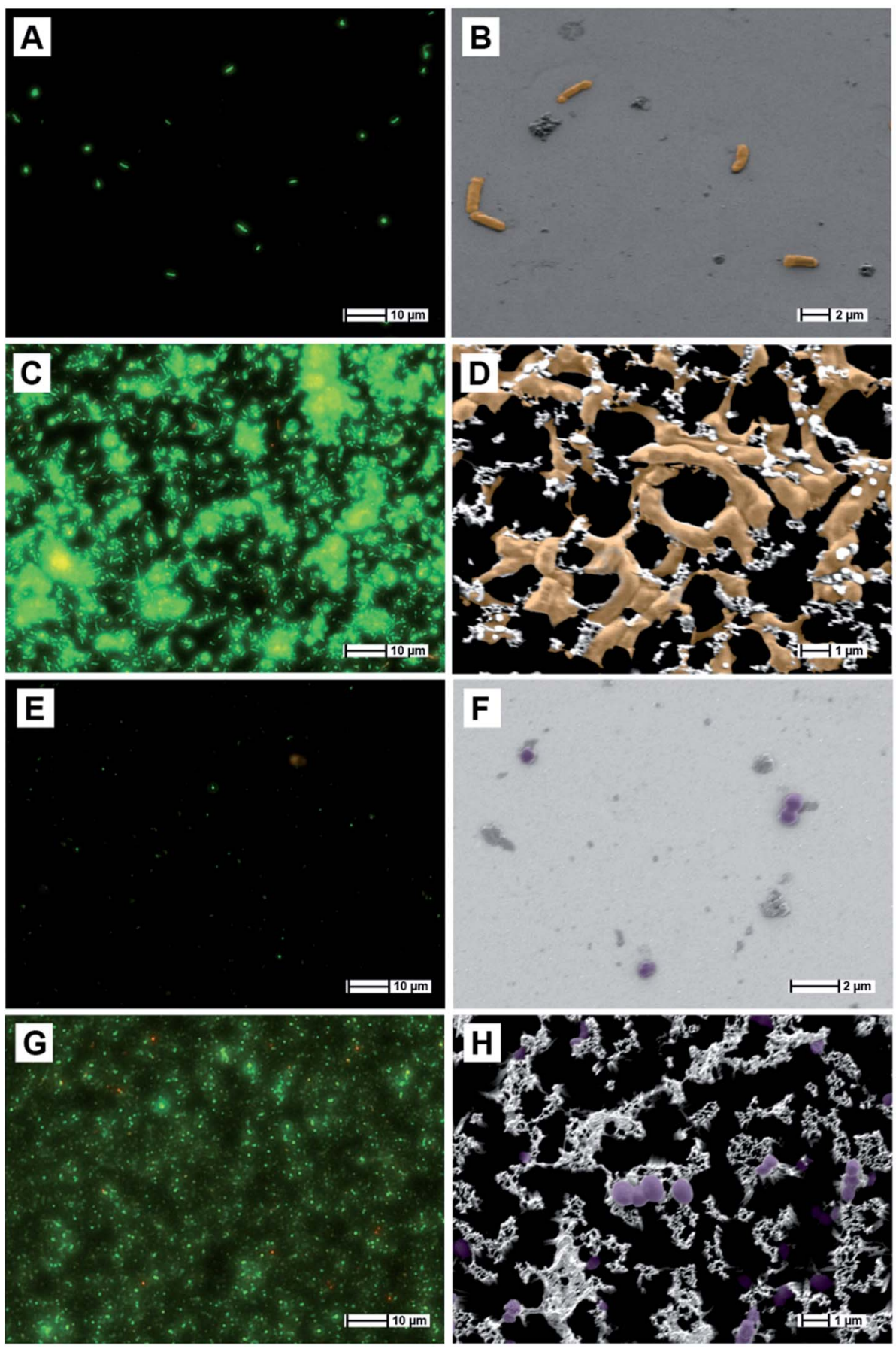

Fig. 2 Fluorescence microscopy images (panels in left column) and SEM micrographs (panels in right column) acquired from fluorescently labelled bacterial cells grown on flat Si and SiNWs. E. coli cells (false colored in orange) captured on (A and B) flat Si and (C and D) SiNWs. S. aureus cells (false colored in purple) captured on (E and F) flat Si and ( $G$ and H) SiNWs. Scale bar (A, C, E and G) $=10 \mu \mathrm{m}, \mathrm{scale}$ bar (B and F) $=2 \mu \mathrm{m}$, and scale $\operatorname{bar}(\mathrm{D}$ and $\mathrm{H})=1 \mu \mathrm{m}$.

\subsection{Ag ion release measurements}

A debate has been ongoing regarding the factors affecting the observed antibacterial properties of sub-micron Ag agglomerates and AgNPs. Some studies suggest that the observed antimicrobial activity is governed by the nanoparticle size, where increased antibacterial activity was correlated with decreasing nanoparticle size. ${ }^{41}$ Others attributed this effect to an increased surface area. ${ }^{42-44}$ However, recent studies concluded that the toxic effects were due to $\mathrm{Ag}$ oxidation and $\mathrm{Ag}^{+}$release from the AgNPs. ${ }^{45}$ For example, Lok et al. ${ }^{46}$ show that only partially oxidized AgNPs display antibacterial effects, as compared to non-oxidized $\mathrm{Ag}^{0}$ particles by virtue of the chemisorbed $\mathrm{Ag}^{+}$ slowly diffusing into solution. The correlation between smaller particle size and increased antibacterial activity was attributed 
to enhanced particle reactivity and oxidation rate as a result of the higher surface-to-volume ratio.

In the case of the Ag-decorated SiNWs described in this work, we measured the amount of $\mathrm{Ag}^{+}$released over time by means of anodic stripping voltammetry (AdSV) ${ }^{47}$ in acetate buffer. For the purposes of this measurement, SiNW samples were prepared by MACE and etched for 30,60 , and $90 \mathrm{~min}$, in order to determine if there was a relationship between the etching duration, and the amount of $\mathrm{Ag}^{+}$released over time. Each of these samples was immersed in $1 \mathrm{~mL}$ of acetate buffer $(\mathrm{pH} 4.0)$ for 12,24 , and $48 \mathrm{~h}$ to monitor the release kinetics (Fig. 3). Acetate buffer was used instead of PBS (as reported by Mikelova et $a .^{48}$ ) because PBS contains chlorine ions $\left(\mathrm{Cl}^{-}\right)$which bind to the $\mathrm{Ag}^{+}$in solution, resulting in $\mathrm{AgCl}$ precipitation and false concentration measurements. Each of the samples were measured in triplicates $(n=3)$.

From the results depicted in Fig. 3, we determined that all the samples $\left(25 \mathrm{~mm}^{2}\right)$ showed a sustained release of $\mathrm{Ag}^{+}$, but with slower kinetics after $24 \mathrm{~h}$. After $48 \mathrm{~h}$ of release, it was observed that the SiNW sample etched for $30 \mathrm{~min}$ exhibited a marginally higher release of $\mathrm{Ag}^{+}\left(0.62 \mu \mathrm{g} \mathrm{mL} \mathrm{m}^{-1}\right)$, as compared to the samples etched for $60 \mathrm{~min}\left(0.56 \mu \mathrm{g} \mathrm{mL}^{-1}\right)$ and $90 \mathrm{~min}$ $\left(0.50 \mu \mathrm{g} \mathrm{mL}{ }^{-1}\right)$. A single-factor ANOVA test resulted in a $p$-value of $<0.02472$, and therefore the statistical difference for $\mathrm{Ag}^{+}$ release between the three substrates after $48 \mathrm{~h}$ was significant with a 95\% confidence level. These concentrations were approximately 100 -fold higher than those reported for antimicrobial polyamide/Ag composites analyzed over the same time frame ( $48 \mathrm{~h}, 6 \times 10^{-3}$ to $\left.15 \times 10^{-3} \mu \mathrm{g} \mathrm{mL} \mathrm{m}^{-1}\right){ }^{49}$

In order to determine the total amount of $\mathrm{Ag}$ available on the surfaces (per unit area), $3^{\prime \prime}$ silicon wafers were etched under the same conditions as the samples used so far for a duration of $30 \mathrm{~min}$. The amount of Ag deposited on the surface after MACE was measured by weighing the wafers initially, followed by dissolving the $\mathrm{Ag}$ in concentrated $\mathrm{HNO}_{3}$. Once the wafers were washed and dried, their weight was measured again. The difference in weight was attributed to the mass of Ag lost by Ag dissolution. This was determined to be $404 \pm 23 \mu \mathrm{g} \mathrm{cm}^{-2}$ (measured in triplicates) or around $101 \mu \mathrm{g}$ per $25 \mathrm{~mm}^{2}$. Furthermore, from Fig. 3, it was determined that $0.62 \mu \mathrm{g}$ was

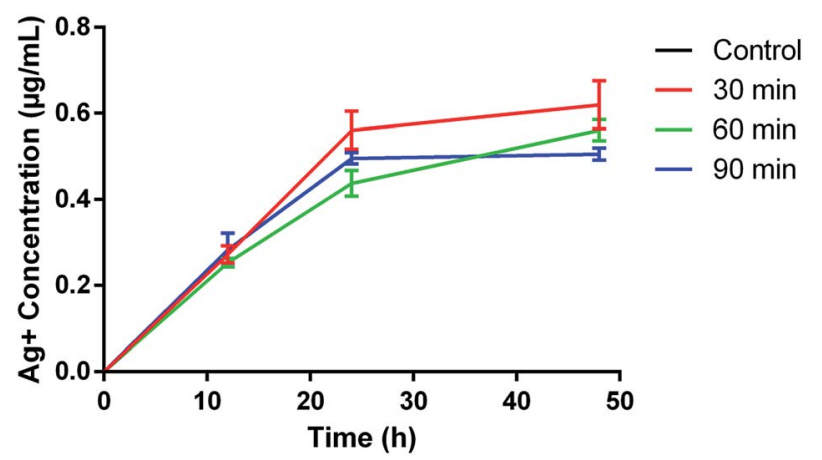

Fig. 3 Ag(I) release rate into acetate buffer $(\mathrm{pH} 4.0)$ over $48 \mathrm{~h}$ from $\mathrm{Ag}$ decorated SiNWs surfaces ( $25 \mathrm{~mm}^{2}$ each) measured by AdSV. The control sample was treated with $\mathrm{HNO}_{3}$ to dissolve surface-bound $\mathrm{Ag}$ prior to the electrochemical measurements. Each measurement was carried out in triplicates $(n=3)$. released into $1 \mathrm{~mL}$ solution per $25 \mathrm{~mm}^{2}$ of SiNW sample. Therefore, the amount released after $48 \mathrm{~h}$ was found to be $<1 \%$ of the $\mathrm{Ag}^{0}$ available on the $25 \mathrm{~mm}^{2}$ sample.

\subsection{Calculating the minimum inhibitory concentration (MIC) of Ag ions}

Silver nitrate $\left(\mathrm{AgNO}_{3}\right)$ was dissolved in TSB at various concentrations and mixed with bacteria-innoculated TSB solutions $\left(10^{8}\right.$ $\mathrm{CFU} \mathrm{mL}{ }^{-1}$ ) for both E. coli and S. aureus strains. Bacteria were allowed to grow overnight in TSB while measuring the turbidity of the solutions at $600 \mathrm{~nm}$ every $2 \mathrm{~h}$ (Fig. 4). For E. coli, a concentration of $10 \mu \mathrm{g} \mathrm{mL} \mathrm{m}^{-1} \mathrm{of} \mathrm{Ag}^{+}$was found to cause a $18 \mathrm{~h}$ delay in the transition to a logarithmic growth phase, compared to a $2 \mathrm{~h}$ delay for the control sample. However, up to $100 \mu \mathrm{g} \mathrm{mL} \mathrm{L}^{-1}$ of $^{\mathrm{Ag}^{+}}$was required to cause a complete growth inhibition.

For S. aureus, it was found that $10 \mu \mathrm{g} \mathrm{mL} \mathrm{m}^{-1}$ of $\mathrm{Ag}^{+}$only caused a $10 \mathrm{~h}$ delay in the onset of the logarithmic growth phase, compared to $2 \mathrm{~h}$ for the control sample. Additionally, similar to E. coli strain, no growth was observed for $S$. aureus at $\mathrm{Ag}^{+}$ concentrations above $100 \mu \mathrm{g} \mathrm{mL} \mathrm{m}^{-1}$.

In order to calculate the minimum inhibitory concentration (MIC) as the lowest $\mathrm{AgNO}_{3}$ concentration that prevents any
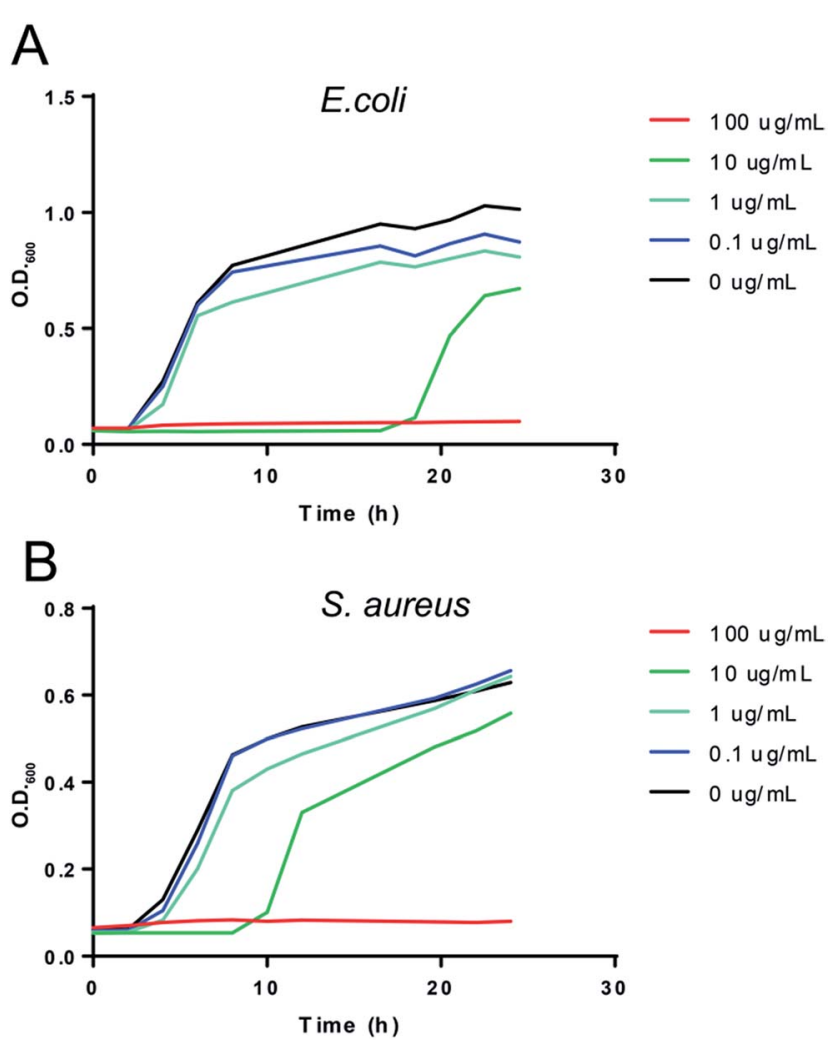

Fig. 4 Optical density of bacterial solution measured at $600 \mathrm{~nm}$ as a function of time where measurements were taken every $2 \mathrm{~h}$ for up to $24 \mathrm{~h}$ and for different $\mathrm{AgNO}_{3}$ concentrations. The optical density is a measure of solution turbidity and corresponds to the number of bacterial cells in solution, namely, E. coli (graph A) and S. aureus (graph B). Both strains were grown in TSB containing a series of $\mathrm{AgNO}_{3}$ dilutions from $100 \mu \mathrm{g} \mathrm{mL}^{-1}$ down to $0 \mu \mathrm{g} \mathrm{mL}^{-1}$. 


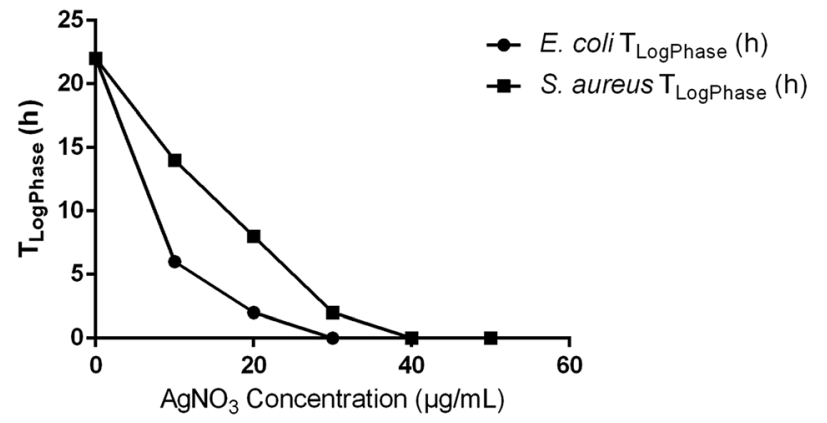

Fig. 5 Plot showing the $T_{\text {log phase }}$ of $E$. coli and $S$. aureus as a function of the concentration of $\mathrm{AgNO}_{3}$ in the growth media.

visible bacterial growth after $24 \mathrm{~h}$ of incubation, ${ }^{46,50}$ TSB solutions containing $\mathrm{AgNO}_{3}$ concentrations ranging between 10 and $100 \mu \mathrm{g} \mathrm{mL} \mathrm{mL}^{-1}$ were prepared. Both $E$. coli and $S$. aureus $\left(10^{8} \mathrm{CFU} \mathrm{mL} \mathrm{m}^{-1}\right)$ were grown in $1 \mathrm{~mL}$ of each TSB solution, and the turbidity was measured again over $24 \mathrm{~h}$ (Fig. S2 $\dagger$ ). A plot representing $24 \mathrm{~h}$ minus the amount of time it took for the culture to enter into logarithmic growth phase $\left(T_{\log \text { phase }}=24-\right.$ (time to log growth)), vs. the concentration of $\mathrm{AgNO}_{3}$ in solution is shown in Fig. 5. For E. coli, the MIC as defined above was found to be $\sim 30 \mu \mathrm{g} \mathrm{mL} \mathrm{m}^{-1}$ of $\mathrm{AgNO}_{3}$. The MIC for $S$. aureus was

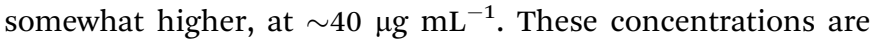
similar to those reported in the literature. ${ }^{51}$

\subsection{Bactericidal effects of Ag-decorated SiNWs}

Although the concentration of $\mathrm{Ag}^{+}$released by $\mathrm{Ag}$-decorated SiNWs was far below the calculated MIC for both bacteria (0.62 $\mu \mathrm{g} \mathrm{mL}^{-1}$ released after $\left.48 \mathrm{~h} v s .30-40 \mu \mathrm{g} \mathrm{mL}{ }^{-1}\right)$, bacterial cells adhered to the SiNWs are obviously exposed to a much higher effective concentration of $\mathrm{Ag}^{+}$since $99 \%$ of the total $\mathrm{Ag}^{0}$ mass was still embedded within the SiNWs network in close proximity to the surface in the form of crystalline dendrites. We therefore decided to assess the close-range bacterial growth inhibition efficiency of the Ag-decorated SiNWs. TSB solutions containing $10^{8} \mathrm{CFU} \mathrm{mL} \mathrm{m}^{-1}$ of either $E$. coli or $S$. aureus were deposited on samples of Ag-decorated SiNWs and Ag-free SiNWs (both etched for $30 \mathrm{~min}$ ), and the bacterial solutions were incubated over the SiNWs for $1 \mathrm{~h}$ at $37^{\circ} \mathrm{C}$. The small amount of bacterial solution volume $(50 \mu \mathrm{L})$ spread out and formed a thin droplet few millimetres in diameter, which covered the entire surface of the sample. This insured that the majority of the bacteria in solution were in close proximity to the SiNWs. The $30 \mathrm{~min}$ etched SiNWs were chosen since they
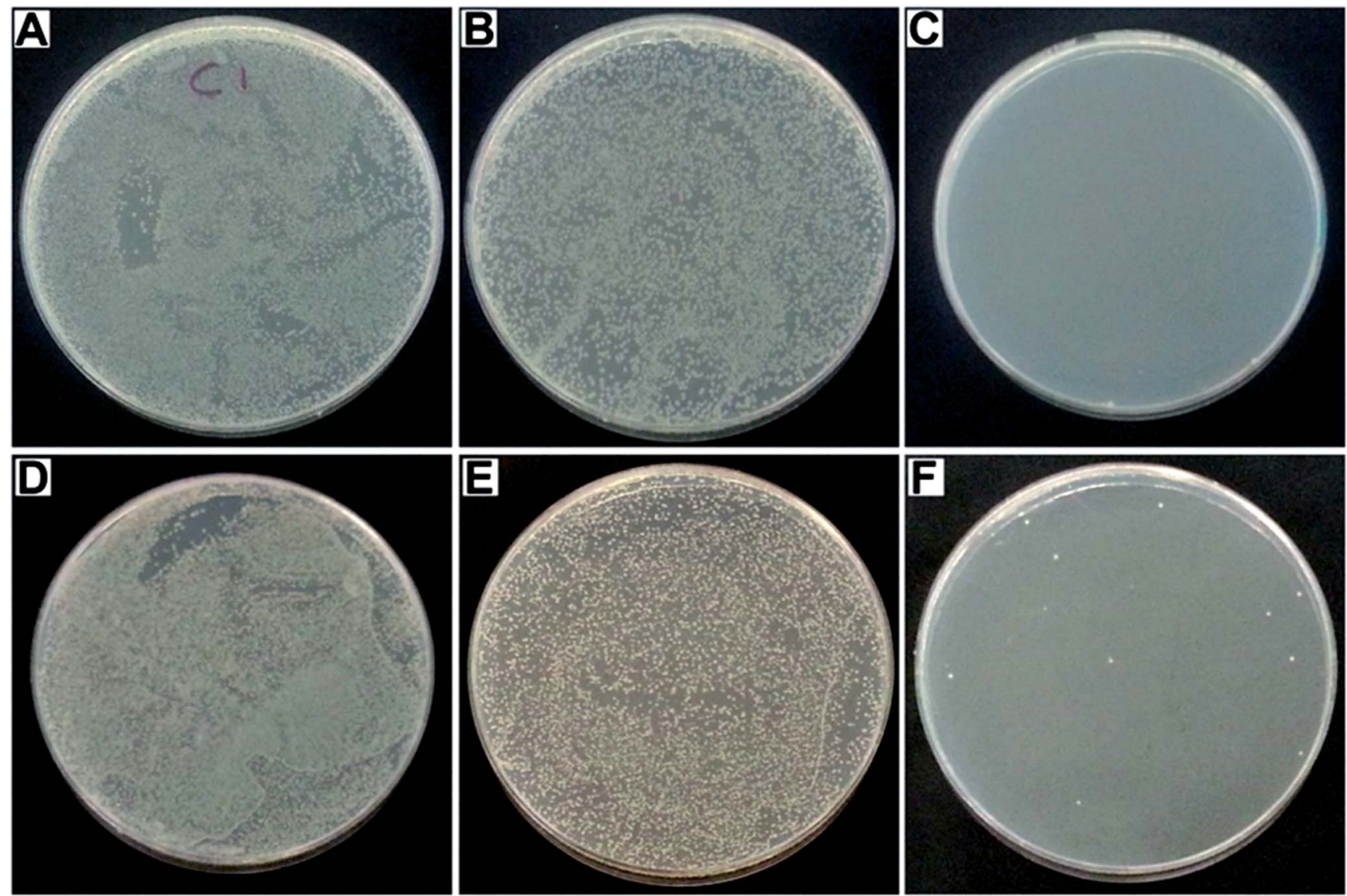

Fig. 6 Optical images of LB-agar plates after incubation of SiNWs. The top row corresponds to E. coli colonies spread onto the plates from solutions that had been incubated for $1 \mathrm{~h}(\mathrm{~A})$ on a 96 well plate, (B) on Ag-free SiNWs and (C) Ag-decorated SiNWs. Similarly, the bottom row presents S. aureus colonies spread on LB-agar plates that had been incubated (D) on a 96 well plate, (E) on Ag-free SiNWs and (F) on Agdecorated SiNWs. 
demonstrated the highest $\mathrm{Ag}^{+}$release compared to the $60 \mathrm{~min}$ and $90 \mathrm{~min}$ etched SiNWs under the same conditions. Following that incubation step, the solution was recovered, diluted further in TSB, and spread on Luria Broth agar (LB-agar) plates and incubated for $16 \mathrm{~h}$ at $37^{\circ} \mathrm{C}$. Optical photographs of the LB-agar plates shown in Fig. 6 gave evidence of strong antibacterial properties of Ag-decorated SiNWs. Fig. 6A and D demonstrate the uninhibited growth of $E$. coli and $S$. aureus, respectively, from control samples that were initially incubated in a 96 well plate (as opposed to incubation over SiNWs). The bacterial lawn in both cases was dense and continuous as expected. The bacterial solutions incubated on SiNWs without Ag coatings (shown in Fig. 6B and $\mathrm{E}$ for $E$. coli and $S$. aureus, respectively) resulted in a similar bacterial lawn density to the control samples. However, bacteria incubated onto Agdecorated SiNWs displayed a near complete growth inhibition for $E$. coli as shown in Fig. 6C. Similarly, the growth of $S$. aureus incubated on Ag-decorated SiNWs was severely limited (Fig. 6F). Unlike $E$. coli however, the $S$. aureus strain was more resistant to the presence of $\mathrm{Ag}$ as evidenced by the presence of a few surviving colonies on the LB-agar. This result was consistent with the outcomes of the MIC assay.

To further confirm the results of the agar-plating test, solutions containing both strains of bacteria incubated in a 96-well plate, on Ag-free SiNWs, and on Ag-decorated SiNWs (for $1 \mathrm{~h}$ ) were recovered, diluted in TSB solutions and allowed to grow in an incubator at $37{ }^{\circ} \mathrm{C}$ for $24 \mathrm{~h}$. The solution turbidity was monitored at $600 \mathrm{~nm}$ at $2 \mathrm{~h}$ intervals for $24 \mathrm{~h}$. The increase in optical density as a measure of turbidity over time was plotted in Fig. 7 for both $E$. coli and $S$. aureus.

The initial lag phase for both $E$. coli and $S$. aureus shifted to logarithmic growth after $2 \mathrm{~h}$ of incubation time as is shown in Fig. 7A and B (for E. coli and S. aureus, respectively) in the case of the control samples. This timeframe is typical for both strains in the absence of any growth-limiting factors. The $E$. coli and $S$. aureus samples grown on Ag-free SiNWs entered the logarithmic growth phase after a 1-2 h delay compared to the control samples, thus indicating that the incubation over SiNWs by itself resulted in a small but noticeable increase in the length of the lag phase.

However, the presence of $\mathrm{Ag}$ agglomerates on the $\mathrm{Ag}$ decorated SiNWs resulted in a significant delay to the onset of the logarithmic growth phase of both bacterial strains. In the case of $E$. coli, the delay was measured at $14 \mathrm{~h}$ relative to the control sample (Fig. 7A), while for $S$. aureus, the delay was found to be around $8 \mathrm{~h}$ relative to the control sample. This delay has to be attributed to the antibacterial effects of the $\mathrm{Ag}^{+}$present in the vicinity of the SiNW arrays on which the bacteria initially attached, resulting in a decrease in the number of viable bacteria able to undergo cellular division. The fact that $S$. aureus suffered a shorter time delay in entering the logarithmic growth phase compared to $E$. coli was consistent with the $\mathrm{Ag}^{+} \mathrm{MIC}$ results obtained for both $S$. aureus and $E$. coli, given that one can safely assume that the amount of $\mathrm{Ag}^{+}$released from SiNWs was more or less the same.

To confirm the hypothesis that bacterial toxicity is a result of $\mathrm{Ag}^{+}$present close to the SiNWs (rather than $\mathrm{Ag}^{+}$dissolved in solution), fresh TSB solution was incubated on Ag-decorated SiNWs for a duration of $2 \mathrm{~h}$. This way, any $\mathrm{Ag}^{+}$release from the Ag-decorated SiNWs would have been contained in the TSB solution. Next, the same TSB solution was inoculated either with $E$. coli or $S$. aureus, and the bacteria were allowed to grow in an incubator, while measuring the solution turbidity over time. The results contained in Fig. 7A and B (labeled as "Off-SiNWs") demonstrate that growth rates of both bacteria strains followed the growth curve of the control cultures closely. This indicated that bacteria grown in TSB solution that was merely exposed to Ag-decorated SiNWs (without the bacterial cells themselves being in intimate contact the SiNWs) did not cause any measurable toxic effects to the bacteria.

From these results it appeared that the Ag existed in equilibrium of oxidized/reduced states $\left(\mathrm{Ag}^{0} \leftrightarrow \mathrm{Ag}^{+}+\mathrm{e}^{-}\right)$within the solution. As the $\mathrm{Ag}^{+}$is consumed through interference with bacterial processes, more SiNWs-bound $\mathrm{Ag}^{0}$ is oxidized to $\mathrm{Ag}^{+}$in order to satisfy the equilibrium, creating an $\mathrm{Ag}^{+}$rich region in close proximity to the SiNWs, which contributed to the observed toxicity against bacteria grown directly on the surface of the Agdecorated SiNWs.

Finally, in order to assess the viability of the bacterial cells attached to Ag-free and Ag-decorated SiNWs after $1 \mathrm{~h}$
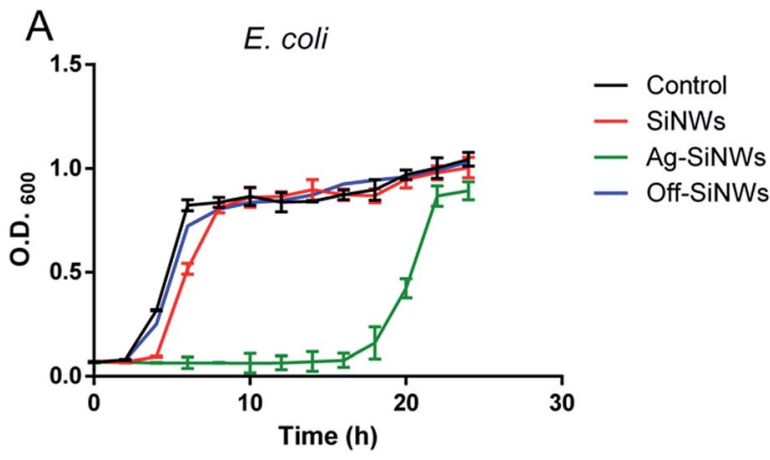

B

S. aureus
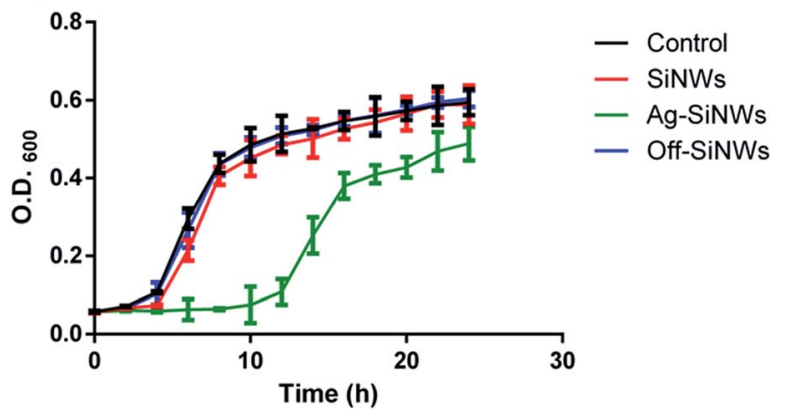

Fig. 7 Increase in turbidity of bacteria innoculated TSB solutions over time, where (A) corresponds to E. coli, and (B) to $S$. aureus growth. The optical density was measured at $600 \mathrm{~nm}$ and was used as a measure of turbidity, which in turn corresponded to the concentration of bacteria in solution. In each case, the bacterial solution was incubated in 96 well plates (control), on Ag-free SiNWs (SiNWs), on Ag-decorated SiNWs (Ag-SiNWs), and in solution that was previously exposed to Agdecorated SiNWs (Off-SiNWs). The measurements were taken every 2 $\mathrm{h}$ in triplicates $(n=3)$ for a duration of $24 \mathrm{~h}$. The error bars represent standard deviation calculated from three values. 
incubation, a Live/Dead assay was used. The assay kit contained the green fluorescent nuclear counter-stain SYTO 9 which binds to the DNA of both Gram-positive and Gram-negative bacteria non-selectively to provide a total count of the number of bacterial cells present, in addition to the red fluorescent propidium iodide (PI) which can only penetrate compromized bacterial cell-walls, and thus indicates cell death. Fluorescence microscopy analysis of the stained samples along with normalized quantitative viability measurements are shown in Fig. 8 and 9, respectively.

Performing this analysis on Ag-decorated SiNWs proved difficult, since there was a strong presence of background fluorescence due to the interaction between the stains and the Ag deposits, preventing an accurate measurement of cell counts. Therefore, bacteria were recovered from SiNW substrates, then mixed with the assay stains, and deposited
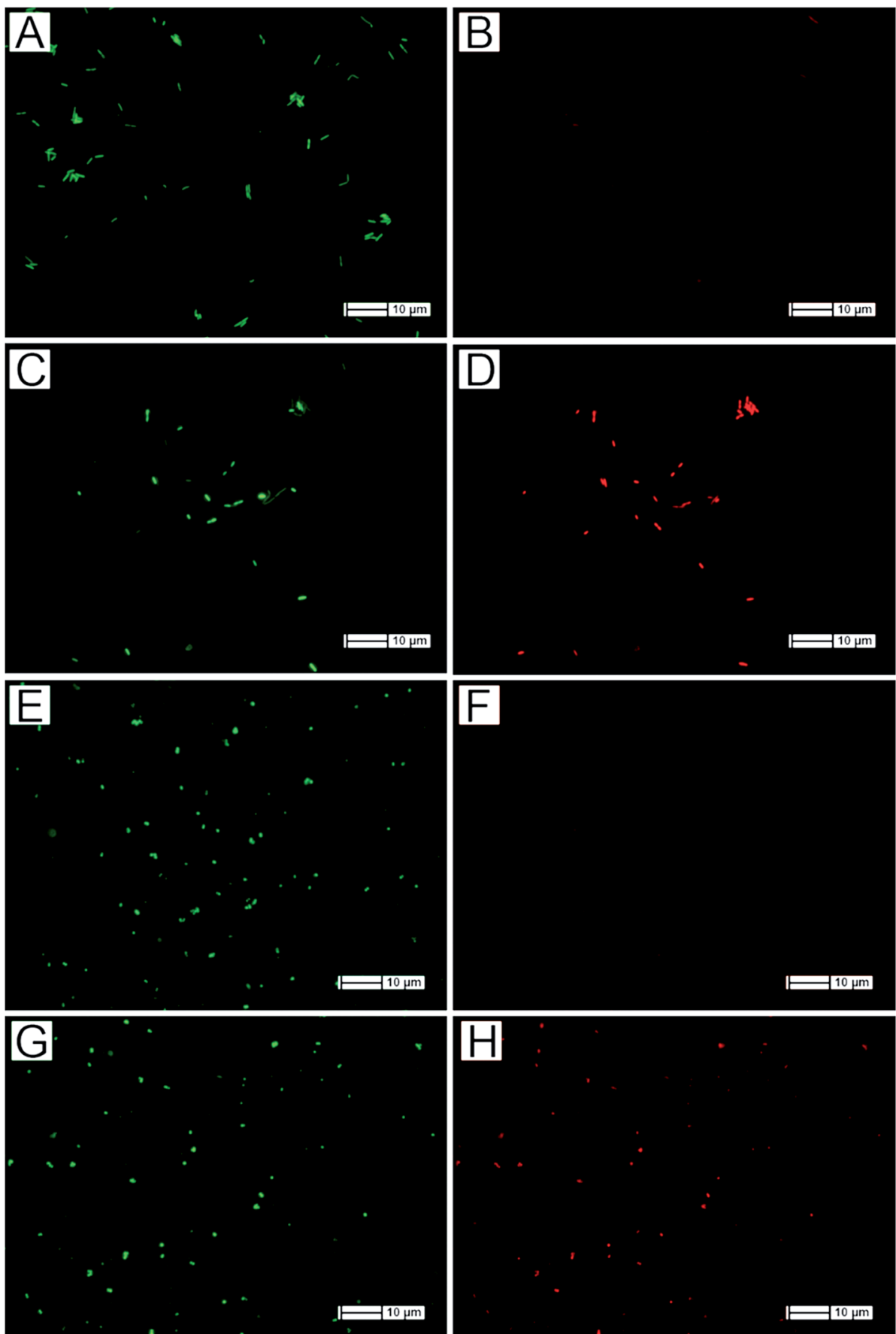

Fig. 8 Fluorescence microscopy images of bacteria after $1 \mathrm{~h}$ incubation SiNW surfaces. The green channel (panels in left column) shows all cells (Syto 9) and the red channel (PI, right column) only dead cells with compromized cell walls. (A and B) correspond to $E$. coli cells grown on Ag-free SiNWs. (C and D) show E. coli cells grown on Ag-decorated SiNWs. (E and F) show S. aureus cells grown on Ag-free SiNWs, while $(G$ and $H$ ) show S. aureus cells grown on Ag-decorated SiNWs. Scale bar $=10 \mu \mathrm{m}$ for each panel. 


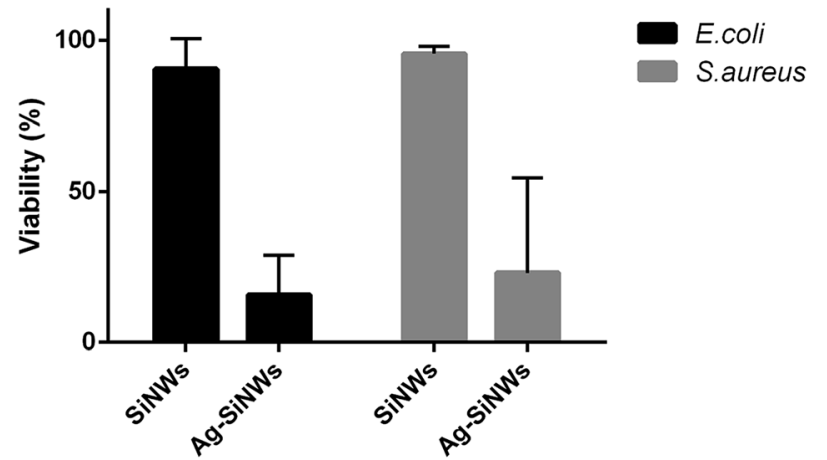

Fig. 9 Percentage (\%) of cell viability for bacterial colonies of E. coli and S. aureus grown on SiNWs with and without Ag-coating. This experiment was performed in triplicates $(n=3)$. Error bars indicate the standard deviation measured from triplicate measurements.

onto glass microscope slides for fluorescence microscopy analysis.

Fig. 8A and B depict E. coli incubated on Ag-free SiNWs, where panel (A) corresponds to the green fluorescence of SYTO 9, and panel (B) corresponds to the red-fluorescence of PI. The majority of the $E$. coli cells only gave green fluorescence, indicating that the integrity of the cell walls was preserved. In contrast, the majority of $E$. coli cells recovered from Agdecorated SiNWs (Fig. 8C and D) showed strong red fluorescence, thus indicating compromised cell walls. The same trend was observed for $S$. aureus bacteria where a lack of red fluorescence was observed from most bacterial cells incubated over Ag-free SiNWs. However, strong red fluorescence was observed from most of the $S$. aureus cells recovered from Ag-decorated SiNWs. These results confirmed that the delay in entering the logarithmic growth phase for E. coli and S. aureus found in Fig. 7 was mainly due to cellular death during the first hour of incubation on the Ag-decorated SiNWs.

Cell counts were performed to estimate the percentage of cell viability (Fig. 9). The count was performed on three individual
SiNW surfaces for each sample, while also incorporating three measurement sets for each surface $(n=3)$. The viability of cells was obtained by subtracting the number of red fluorescent cells (dead cells) from the number of green fluorescent cells (total number of cells) and dividing by the total number of cells (see Section 1.6 ESI $\dagger$ ). E. coli cells incubated on Ag-free SiNWs showed a viability of $91 \pm 10 \%$ compared to only $16 \pm 13 \%$ for cells incubated on Ag-decorated SiNWs ( $p$-value < 0.00142; 95\% confidence). On the other hand, the $S$. aureus cells viability rate after incubation on $\mathrm{Ag}$-free SiNWs was found to be at $96 \pm 2 \%$ as compared to $23 \pm 3 \%$ for those cells that were incubated over Ag-decorated SiNWs ( $p$-value $<0.01652 ; 95 \%$ confidence). Hence, the Ag-decorated SiNWs caused a fivefold reduction in viability for $E$. coli and a fourfold reduction in viability for $S$. aureus cells due to the effect of the surface-bound Ag.

\subsection{Mammalian cell viability and attachment}

Human foreskin fibroblast (HFF) cells were grown on Agdecorated SiNWs and on Ag-free SiNWs to determine whether the SiNWs had an intrinsic toxic effect upon mammalian cells. Finally, HFF cells were grown on flat silicon surfaces and in cellculture well plates as negative controls for a duration of $48 \mathrm{~h}$ preceded by a washing step after $2 \mathrm{~h}$ of incubation to remove loosely attached cells. Cell viability results in Fig. 10A show that no negative effect on the viability of the HFF cells was observed on either Ag-free and Ag-decorated SiNWs. In fact, the percentage of viability of HFF cells grown on SiNWs was almost equal to the percentage of viability of cells grown in cell culture well plates. This shows that the small amount of $\mathrm{Ag}^{+}$released by these surfaces was only lethal against bacteria and not against mammalian cells.

Furthermore, we observed that the HFF cells had a very low attachment rate to the SiNW arrays compared to flat Si or well plates (Fig. 10B), potentially contributing to the low toxicity since most cells would not experience the high effective concentrations of $\mathrm{Ag}^{+}$in proximity to the nanowire surfaces. Therefore, it is safe to postulate that this particular morphology
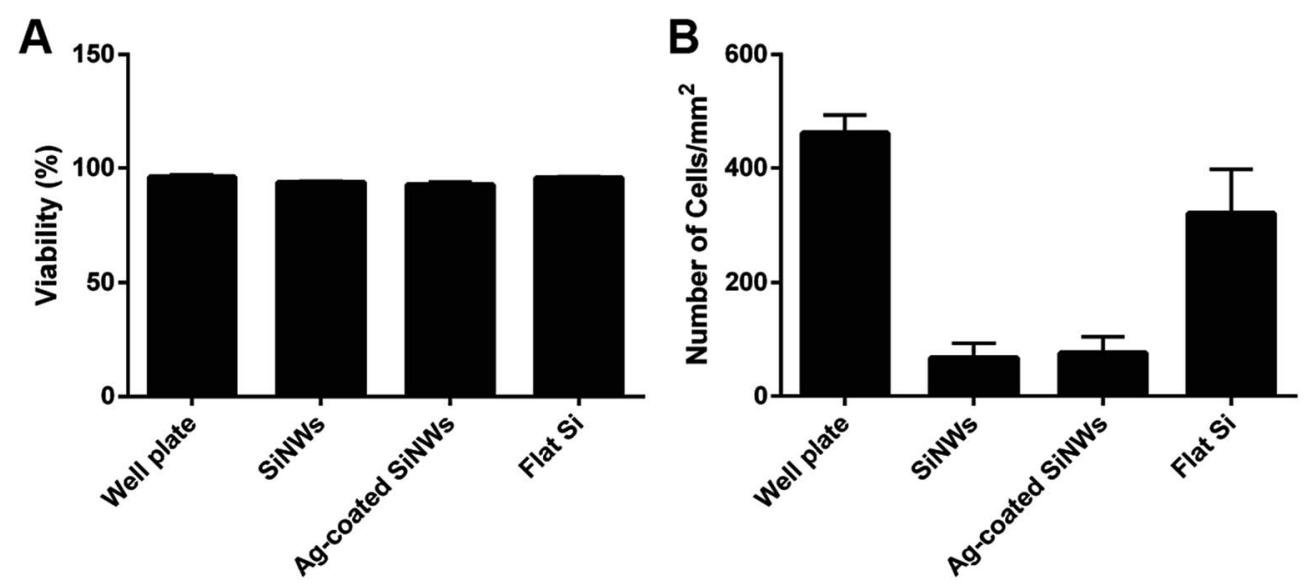

Fig. 10 Graph (A) shows HFF cell viability (\%) after being grown on Ag-free and Ag-decorated SiNWs as well as in cell-culture well-plates and on flat Si. (B) shows the attachment of HFF cells to Ag-free and Ag-decorated SiNWs as well as cell-culture well plates and flat Si for $2 \mathrm{~h}$. Error bars represent 3 replicates for each sample. 
of SiNW arrays promotes bacterial cell attachment (Fig. 2), while at the same time discouraging mammalian cells.

\section{Conclusions}

In this work, we assessed the efficacy of SiNWs fabricated by means of MACE as antibacterial substrates. The bacterial adhesion efficiency was measured for the SiNWs relative to flat Si substrates, and the results showed a greater than 100 fold increase in the amount of bacteria adhesion for both Gramnegative $E$. coli and Gram-positive $S$. aureus. Additionally, the capturing efficiency for $E$. coli was three times higher than for $S$. aureus. The amount of $\mathrm{Ag}^{+}$ions release from Ag-decorated SiNWs was measured and three different etching durations were compared. In this case, 30 min etched samples showed the highest release of $\mathrm{Ag}^{+}$. Finally, the bactericidal effects of Agdecorated SiNWs against $E$. coli and $S$. aureus was assessed relative to Ag-free SiNWs and 96 well plates, using LB-agar plating, turbidity monitoring, and Live/Dead assay tests. The results confirmed growth inhibition for a duration of up to $18 \mathrm{~h}$ and $10 \mathrm{~h}$ for $E$. coli and $S$. aureus, respectively. In comparison, the control bacteria grown in 96 well plates and on Ag-free SiNWs entered their logarithmic growth phase within $2 \mathrm{~h}$ of incubation. Human fibroblast cells experienced no toxic effects when grown on both Ag-free and Ag-decorated SiNWs, and they also showed very low rates of attachment.

Based on those results, we believe that the Ag-decorated SiNW substrates described here, fabricated in a one-step MACE reaction process, show promise as low-cost and scalable antibacterial platforms with the synergistic capability of capturing and killing bacterial cells in their immediate environment. The SiNW arrays could be potentially transferred into a range of wound bandage materials including hydrogels and electrospun fabrics.

\section{Acknowledgements}

This project was partially funded by the Australian Cooperative Research Centre, Wound Management Innovation (CRC-WMI, 2.05).

\section{Notes and references}

1 L. Hu and G. Chen, Nano Lett., 2007, 7, 3249-3252.

2 B. M. Rey, R. Elnathan, R. Ditcovski, K. Geisel, M. Zanini, M.-A. Fernandez-Rodriguez, V. V. Naik, et al., Nano Lett., 2015, 16(1), 157-163.

3 L. J. Chen, J. Mater. Chem., 2007, 17, 4639-4643.

4 F. Patolsky, G. Zheng and C. M. Lieber, Nat. Protoc., 2006, 1, 1711-1724.

5 Y. Engel, R. Elnathan, A. Pevzner, G. Davidi, E. Flaxer and F. Patolsky, Angew. Chem., Int. Ed., 2010, 49, 6830-6835.

6 H. Z. Alhmoud, T. M. Guinan, R. Elnathan, H. Kobus and N. H. Voelcker, Analyst, 2014, 6000-6010, DOI: 10.1039/ c4an01391c.

7 R. Elnathan, M. Kwiat, F. Patolsky and N. H. Voelcker, Nano Today, 2014, 9, 172-196.
8 R. Elnathan, B. Delalat, D. Brodoceanu, H. Alhmoud, F. J. Harding, K. Buehler, A. Nelson, L. Isa, T. Kraus and N. H. Voelcker, Adv. Funct. Mater., 2015, 25, 7215-7225.

9 C. Chiappini, et al., ECS Trans., 2015, 69(2), 63-68.

10 R. Elnathan, I. Lucio, D. Brodoceanu, A. Nelson, F. J. Harding, B. Delalat, T. Kraus and N. H. Voelcker, ACS Appl. Mater. Interfaces, 2015, 7(42), 23717-23724.

11 K. Peng, Y. Yan, S. Gao and J. Zhu, Adv. Funct. Mater., 2003, 13, 127-132.

12 K. Q. Peng, J. J. Hu, Y. J. Yan, Y. Wu, H. Fang, Y. Xu, S. T. Lee and J. Zhu, Adv. Funct. Mater., 2006, 16, 387-394.

13 M.-L. Zhang, K.-Q. Peng, X. Fan, J.-S. Jie, R.-Q. Zhang, S.-T. Lee and N.-B. Wong, J. Phys. Chem. C, 2008, 112, 4444-4450.

14 C. Chiappini, X. Liu, J. R. Fakhoury and M. Ferrari, Adv. Funct. Mater., 2010, 20, 2231-2239.

15 S. J. Pearton, T. Lele, Y. Tseng and F. Ren, Trends Biotechnol., 2007, 25, 481-482.

16 Y. Su, X. Wei, F. Peng, Y. Zhong, Y. Lu, S. Su, T. Xu, S.-T. Lee and Y. He, Nano Lett., 2012, 12, 1845-1850.

17 O. Fellahi, R. K. Sarma, M. R. Das, R. Saikia, L. Marcon, Y. Coffinier, T. Hadjersi, M. Maamache and R. Boukherroub, Nanotechnology, 2013, 24, 495101.

18 Y. Q. Li, B. Zhu, Y. Li, W. R. Leow, R. Goh, B. Ma, E. Fong, M. Tang and X. Chen, Angew. Chem., Int. Ed., 2014, 53, 5837-5841.

19 M. Lv, S. Su, Y. He, Q. Huang, W. Hu, D. Li, C. Fan and S. T. Lee, Adv. Mater., 2010, 22, 5463-5467.

20 K. Page, M. Wilson and I. P. Parkin, J. Mater. Chem., 2009, 19, 3819-3831.

21 E. P. Ivanova, J. Hasan, H. K. Webb, G. Gervinskas, S. Juodkazis, V. K. Truong, A. H. Wu, R. N. Lamb, V. A. Baulin and G. S. Watson, Nat. Commun., 2013, 4, 2838.

22 H. Wang, L. Wang, P. Zhang, L. Yuan, Q. Yu and H. Chen, Colloids Surf., B, 2011, 83, 355-359.

23 K. S. Brammer, C. Choi, S. Oh, C. J. Cobb, L. S. Connelly, M. Loya, S. D. Kong and S. Jin, Nano Lett., 2009, 9, 35703574.

24 S. Percival, P. Bowler and D. Russell, J. Hosp. Infect., 2005, 60, 1-7.

25 B. S. Atiyeh, M. Costagliola, S. N. Hayek and S. A. Dibo, Burns, 2007, 33, 139-148.

26 K. Peng and J. Zhu, Electrochim. Acta, 2004, 49, 2563-2568.

27 T. Qiu, X. L. Wu, G. G. Siu and P. Chu, J. Electron. Mater., 2006, 35, 1879-1884.

28 Y. Yang and G. Meng, J. Appl. Phys., 2010, 107, 044315.

29 W. Ye, C. Shen, J. Tian, C. Wang, L. Bao and H. Gao, Electrochem. Commun., 2008, 10, 625-629.

30 J. Meng, P. Zhang and S. Wang, Chem.-Asian J., 2014, 9, 2004-2016.

31 R. D. Boyd, J. Verran, M. V. Jones and M. Bhakoo, Langmuir, 2002, 18, 2343-2346.

32 K. A. Whitehead, D. Rogers, J. Colligon, C. Wright and J. Verran, Colloids Surf., B, 2006, 51, 44-53.

33 R. J. Crawford, H. K. Webb, V. K. Truong, J. Hasan and E. P. Ivanova, Adv. Colloid Interface Sci., 2012, 179-182, 142-149. 
34 E. P. Ivanova, J. Hasan, H. K. Webb, V. K. Truong, G. S. Watson, J. A. Watson, V. A. Baulin, S. Pogodin, J. Y. Wang, M. J. Tobin, C. Löbbe and R. J. Crawford, Small, 2012, 8, 2489-2494.

35 J. Ma, Y. Sun, K. Gleichauf, J. Lou and Q. Li, Langmuir, 2011, 27, 10035-10040.

36 P. S. Stewart and J. W. Costerton, Lancet, 2001, 358, 135-138.

37 J. W. Costerton, P. S. Stewart and E. Greenberg, Science, 1999, 284, 1318-1322.

38 M. Zhang, K. Zhang, B. De Gusseme and W. Verstraete, Water Res., 2012, 46, 2077-2087.

39 R. Diggikar, R. Patil, S. Kale, D. Thombre, W. Gade, M. Kulkarni and B. Kale, Appl. Microbiol. Biotechnol., 2013, 97, 8283-8290.

40 D. Bakkiyaraj and S. K. Pandian, in Antibiofilm Agents, ed. K. P. Rumbaugh and I. Ahmad, Springer, Berlin Heidelberg, 2014, vol. 8, ch. 17, pp. 385-406.

41 G. Martinez-Castanon, N. Nino-Martinez, F. MartinezGutierrez, J. Martinez-Mendoza and F. Ruiz, J. Nanopart. Res., 2008, 10, 1343-1348.
42 S. H. Jeong, Y. H. Hwang and S. C. Yi, J. Mater. Sci., 2005, 40, 5413-5418.

43 J. Thiel, L. Pakstis, S. Buzby, M. Raffi, C. Ni, D. e. J. Pochan and S. I. Shah, Small, 2007, 3, 799-803.

44 L. Liu, C. He, J. Li, J. Guo, D. Yang and J. Wei, New J. Chem., 2013, 37, 2179-2185.

45 Z.-m. Xiu, Q.-b. Zhang, H. L. Puppala, V. L. Colvin and P. J. Alvarez, Nano Lett., 2012, 12, 4271-4275.

46 C.-N. Lok, C.-M. Ho, R. Chen, Q.-Y. He, W.-Y. Yu, H. Sun, P.-H. Tam, J.-F. Chiu and C.-M. Che, JBIC, J. Biol. Inorg. Chem., 2007, 12, 527-534.

47 C. Radheshkumar and H. Münstedt, React. Funct. Polym., 2006, 66, 780-788.

48 R. Mikelova, J. Baloun, J. Petrlova, V. Adam, L. Havel, J. Petrek, A. Horna and R. Kizek, Bioelectrochemistry, 2007, 70, 508-518.

49 R. Kumar and H. Münstedt, Biomaterials, 2005, 26, 20812088.

50 M. G. Guzmán, J. Dille and S. Godet, Int. J. Chem. Biomol. Eng., 2009, 2, 104-111.

51 H. Kong and J. Jang, Langmuir, 2008, 24, 2051-2056. 